\title{
Meningkatkan minat dan hasil belajar sistem bahan bakar bensin dengan metode think pair share di SMK Muhammadiyah Cangkringan
}

\author{
Widiyatmoko Widiyatmoko \\ SMK Muhammadiyah Cangkringan. Jl. Pakem - Kalasan Jetis Argomulyo, Sleman, Daerah Istimewa Yogyakarta, 55583, Indonesia \\ widiyatmoko_yk@yahoo.com \\ * corresponding author
}

ARTICLE INFO

Keywords

Minat Belajar

Hasil Belajar,

Metode Pembelajaran TPS

\begin{abstract}
Tujuan penelitian untuk mengetahui peningkatan minat dan hasil belajar kompetensi sistem bahan bakar bensin dengan penerapan metode pembelajaran kooperatif tipe TPS di kelas XI Kompetensi Keahlian Teknik Kendaraan Ringan (TKR) SMK Muhammadiyah Cangkringan. Penelitian ini merupakan penelitian tindakan kelas (PTK) yang dilaksanakan pada siswa kelas XI Kompetensi Keahlian TKR di SMK Muhammadiyah Cangkringan yang beralamat di Jetis Argomulyo Cangkringan Sleman Yogyakarta. Subjek pada penelitian ini adalah siswa tingkat XI Kompetensi Keahlian TKR yang berjumlah 36 orang siswa. Teknik pengumpulan data dilakukan dengan angket dan soal test, selanjutnya data dianalisis dengan statistik deskriptif. Hasil penelitian menunjukkan bahwa penerapan metode pembelajaran kooperatif tipe TPS pada kompetensi keahlian sistem bahan bakar bensin dapat meningkatkan minat belajar sebesar $8,12 \%$ dan meningkatkan hasil belajar siswa. Data penelitian menunjukkan bahwa pada pra siklus ketuntasan hasil belajar yang memenuhi kriteria ketuntasan minimal (KKM) sebesar 19,44\%, selanjutnya pada siklus I ketuntasan hasil belajar yang mendapai KKM $66,67 \%$, dan pada siklus II ketuntasan hasil belajar yang memenuhi KKM sebesar $86,11 \%$.
\end{abstract}

This is an open access article under the CC-BY-SA license.

\section{PENDAHULUAN}

Sekolah merupakan lembaga pendidikan yang berupaya meningkatkan kualitas pendidikan. Salah satu upaya meningkatkan mutu pendidikan adalah dengan memperbaiki mutu belajar mengajar. Keberhasilan pendidikan sangat bergantung pada proses pembelajaran di kelas. Guru berperan penting dalam proses belajar mengajar karena kreatifitas guru dalam merancang, memilih dan melakukan pendekatan teknik mengajar sangat diperlukan.

Seorang guru dalam melaksanakan pembelajaran hendaknya dapat menggunakan model pembelajaran yang efektif, efesien dan inovatif. Sebagaimana dinyatakan oleh (Huda, 2013, p. 73), bahwa "model pembelajaran didiskripsikan sebagai rencana atau pola yang dapat digunakan untuk membentuk kurikulum, mendesain materi-materi instrucsional, dan memandu proses pengajaran diruang kelas atau disetting yang berbeda". Melalui metode pembelajaran guru dapat membantu siswa mendapatkan informasi, ide, keterampilan, cara berfikir, dan mengekspresikan ide. Kenyataannya 
sedikit guru yang menerapkan inovasi pembelajaran dengan metode-metode tertentu, karenanya seorang guru dituntut mengembangkan keterampilan menerapkan model-model pembelajaran yang belum efektif.

SMK Muhammadiyah Cangkringan adalah sekolah swasta yang sebagian besar siswanya adalah siswa yang tidak diterima masuk pada sekolah negeri. Berdasarkan data nilai dari guru pengampu untuk kompetensi sistem bahan bakar tahun 2015/2016 didapatkan nilai siswa tingkat XI kompetensi keahlian TKR yang memenuhi kriteria minimal (KKM) kurang dari 70\%. Berdasarkan hasil pengamatan, rendahnya motivasi dan tingkat keberhasilan belajar siswa salah satunya disebabkan sebagian besar guru masih menggunakan metode klasikal dalam penyampaian materi.

Berdasarkan permasalahan diatas perlulah dilakukan penelitian tentang metode pembelajaran, salah satunya adalah metode pembelajaran kooperatif tipe Think Pair Share (TPS) yang diharapkan mampu meningkatkan minat dan hasil belajar dalam pembelajaran. Metode pembelajaran kooperatif tipe TPS merupakan salah satu model pembelajaran yang melibatkan siswa sejak perencanaan, baik dalam menentukan topik maupun mempelajarinya. Model pembelajaran ini memberikan kesempatan siswa untuk berpikir dan merespon serta saling membantu satu sama lain.

Menurut Slameto (2013) minat adalah suatu rasa lebih suka atau rasa ketertarikan pada suatu hal atau aktivitas, tanpa ada yang menyuruh. Syah (2013) menerangkan bahwa minat adalah kecenderungan dan kegairahan yang tinggi atau keinginan yang besar terhadap sesuatu. Seseeorang dikatakan berminat terhadap sesuatu bila memiliki beberapa unsur antara lain: perhatian, perasaan senang, ketertarikan, dan keingintahuan. Dari pengertian tersebut jelas bahwa minat merupakan pusat perhatian terhadap suatu objek seperti benda tertentu yang didahului oleh perasaan senang terhadap objek tersebut. Minat akan melahirkan perhatian spontan yang memungkinkan terciptanya konsentrasi untuk waktu yang cukup lama. Dengan demikian minat merupakan landasan dari konsentrasi.

Menurut Good dan Brophy (Uno, 2007, p. 15) mengemukakan belajar merupakan suatu proses atau interaksi yang dilakukan seseorang dalam memperoleh sesuatu yang baru dalam bentuk perubahan tingkah laku sebagai hasil dari pengalaman itu sendiri (belajar). Perubahan perilaku tersebut akan tampak dalam penguasaan siswa pada pola-pola tanggapan (respons) baru terhadap lingkungannya yang berupa keterampilan (skill), kebiasaan (habit), sikap atau pendirian (attitude), kemampuan (ability), pengetahuan (knowledge), pemahaman (understanding), emosi (emosional), apresiasi (apreciation), jasmani dan etika atau budi pekerti, serta hubungan sosial. Adapun (Purwanto, 2011; Winkel, 1983) mengemukakan belajar adalah aktivitas mental atau psikis yang berlangsung dalam interaksi aktif dengan lingkungan yang menghasilkan perubahan-perubahan dalam pengetahuan, keterampilan dan sikap.

Supridjono (2012, p. 2) "learning is to observe, to read, to imitate, to try something, themselves, to listen, to follow direction". Bahwa belajar adalah mengamati, membaca, meniru, mencoba sesuatu, mendengar dan mengikuti arah tertentu. Sehingga belajar senantiasa merupakan perubahan tingkah laku atau penampilan dengan serangkaian kegiatan yang berasal dari diri individu yang didapat dari pengetahuan dan pengalaman.

Berdasarkan beberapa pendapat diatas dapat disimpulkan yang dimaksud minat belajar adalah kecenderungan atau dorongan siswa untuk interaksi dalam memperoleh sesuatu yang baru dalam bentuk perubahan tingkah laku seperti adalah mengamati, membaca, meniru, mencoba sesuatu, mendengar dan mengikuti arah tertentu dalam proses pembelajaran.

Menurut (Gagne, 1985; Purwanto, 2011) mengemukakan hasil belajar adalah terbentuknya konsep, yaitu kategori yang kita berikan pada stimulus yang ada di lingkungan, yang menyediakan skema yang terorganisasi untuk mengasimilasi stimulus-stimulus baru dan menentukan hubungan di dalam dan di antara kategori-kategori. Adapun menurut Sudjana (2010) hasil belajar adalah kemampuan-kemampuan yang dimiliki siswa setelah ia menerima pengalaman belajarnya.

Menurut Supridjono (2012) model pembelajaran merupakan landasan praktik pembelajaran hasil penurunan teori psikologi pendidikan dan teori belajar yang dirancang berdasarkan analisis terhadap implementasi kurikulum dan implementasi pada tingkat operasional dikelas. Senada dengan pendapat Suprijono, menurut (Huda, 2013) menyatakan bahwa model pembelajaran didiskripsikan sebagai 
rencana atau pola yang dapat digunakan untuk membentuk kurikulum, mendesain materi-materi instruksional, dan memandu proses pengajaran diruang kelas atau disetting yang berbeda. Melalui model pembelajaran guru dapat membantu peserta didik mendapatkan informasi, ide, keterampilan, cara berfikir, dan mengekspresikan ide.

Menurut Supridjono (2012) pembelajaran Think Pair Share (TPS) yaitu: (1) Thinking yaitu pembelajaran yang diawali dengan guru mengajukan pertanyaan atau isu terkait dengan pembelajaran untuk dipikirkan oleh peserta didik. Guru memberi kesempatan kepada mereka memikirkan jawabannya, (2) Pairing yaitu guru meminta peserta didik berpasang-pasangan. Beri kesempatan pada pasangan-pasangan untuk berdiskusi. Diharapkan dapat memendam makna dari jawaban yang telah dipikirkannya, (3) Sharing yaitu peserta didik dapat menemukan struktur dari pengetahuan yang dipelajarinya.

Menurut Huda (2012, p. 136) ada beberapa alasan mengapa model pembelajaran tipe Think Pair Share (TPS) perlu digunakan antara lain sebagai berikut: (1) Memungkinkan siswa untuk bekerja sendiri dan bekerja sama dengan orang lain, (2) Mengoptimalkan partisipasi siswa, (3) Memberikan kesempatan banyak kepada setiap siswa untuk menunjukan partisipasi, (4) Bisa diterapkan untuk semua mata pelajaran dan tingkatan kelas.

Dari uraian diatas dapat nyatakan bahwa metode pembelajaran TPS membantu menstrukturkan diskusi dalam proses pembelajaran. Selain itu siswa dikondisikan mengikuti proses yang telah ditentukan. Adanya proses interaksi antara siswa untuk berfikir, berpasangan, dan selanjutnya berdiskusi sangat memungkinkan memberikan stimulan belajar kepada siswa yang akhirnya dapat meningkatkan minat siswa dalam belajar, yang selanjutnya akan meningkatkan pencapaian siswa dalam belajar atau hasil belajar.

\section{METODE}

Penelitian ini adalah Penelitian Tindakan Kelas (PTK) yang dilaksanakan di SMK Muhammadiyah Cangkringan. Adapun subyek penelitian adalah siswa kelas XI Prodi Teknik Otomotif Kompetensi keahlian Teknik Kendaraan Ringan (TKR). Skematis PTK seperti terlihat pada Gambar 1 .

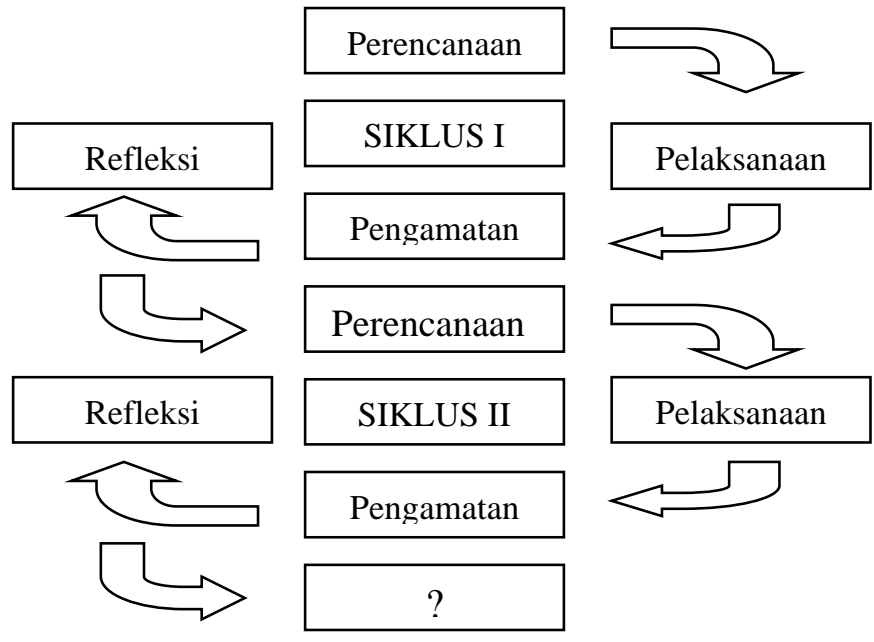

Gambar 1. Alur Penelitian Tindakan Kelas (Arikunto et al., 2010)

\section{Siklus I}

\section{Perencanaan}

Pada tahap ini dilakukan berbagai persiapan dan perencanaan yang meliputi hal berikut: menyusun RPP, mempersiapkan sarana dan prasarana dan media pembelajaran, menyusun lembar kerja siswa, menyusun dan mempersiapkan instrumen/angket, dan mempersiapkan soal evaluasi beserta kunci jawaban. 
Pelaksanaan tindakan

dilakukan dengan menggunakan panduan perencanaan yang telah dibuat, pelaksanaannya bersifat fleksibel dan terbuka terhadap perubahan-perubahan. Tindakan kelas dilaksanakan dengan menggunakan langkah-langkah kegiatan pembelajaran yaitu: kegiatan pendahulun, kegiatan inti, dan penutup.

Kegiatan pendahuluan: (1) Guru membuka pembelajaran, (2) Guru mengadakan apersepsi, sebagai penggalian pengetahuan awal siswa terhadap materi yang akan diajarkan, (3) Guru menyampaikan indikator dan tujuan pembelajaran.

Kegiatan inti: (1) Guru mengarahkan fokus diskusi, dengan menyampaikan strategi diskusi kelas yang akan digunakan yaitu Think Pair Share (TPS) serta menjelaskan aturan-aturan dasarnya, (2) Guru memberikan sedikit penjelasan tentang gambaran materi sistem bahan bakar bensin, (3) Guru membuat kelompok diskusi yang setiap kelompok terdiri atas empat siswa berdasarkan tempat duduk yang terdekat, (4) Guru mengajak siswa untuk berpikir (think) dengan menjawab pertanyaan yang terdapat pada lembar kerja siswa, (5) Guru membagikan lembar kerja dan mengorganisasikan siswa untuk berpasangan (pair) dengan teman sebangkunya, (5) Guru mendorong dan membimbing setiap kelompok pasangan belajar untuk berdiskusi menyelesaikan lembar kerja siswa, (6) Guru meminta pasangan belajar, kembali bersama kelompoknya untuk saling berbagi (share) hasil diskusinya, (7) Guru memilih secara acak kelompok pasangan siswa untuk mempresentasikan hasil diskusinya kepada kelompok pasangan lainnya di depan kelas, (8) Guru membimbing dan mengamati siswa dalam menyampaikan hasil diskusinya, (9) Guru mengarahkan siswa untuk membuat rangkuman mengenai materi sistem bahan bakar bensin, (10) Guru mengarahkan siswa untuk membuat rangkuman mengenai materi sistem bahan bakar bensin.

Kegiatan penutup: (1) Guru memberikan kesimpulan tentang materi yang diajarkan, (2) Guru memberi informasi untuk pertemuan berikutnya ada ulangan materi sistem bahan bakar bensin.

\section{Observasi}

dilaksanakan selama proses pembelajaran sistem bahan bakar bensin dengan model pembelajaran TPS berlangsung untuk melakukan pengamatan mengenai pelaksanaan kegiatan pembelajaran dan mengetahui kegiatan-kegiatan apa saja yang dilakukan guru pada saat proses kegiatan pembelajaran berlangsung. Tahap ini bertujuan untuk mengumpulkan bukti hasil tindakan agar dapat dievaluasi dan dijadikan landasan melakukan refleksi.

\section{Refleksi}

dilakukan untuk mengetahui kelebihan dan kekurangan pembelajaran yaang telah dilaksanakan. Refleksi berdasarkan hasil pegamatan, angket dan tes. Dari hasil refleksi tersebut dapat ditentukan apakah pembelajaran akan dilanjutkan ke tahap berikutnya atau tidak.

\section{Siklus II}

Perencanaan

Penyusunan RPP, dan mempersiapkan instrumen.

\section{Pelaksanaan Tindakan}

Pelaksanaan pembelajaran sesuai dengan RPP yang telah disusun. Proses pembelajaran yang dilaksanakan dengan menerapakan model pembelajaran Think Pair Share (TPS).

\section{Observasi}

Dilaksanakan selama proses pembelajaran sistem bahan bakar bensin dengan model pembelajaran Think Pair Share (TPS) berlangsung untuk melakukan pengamatan mengenai pelaksanaan kegiatan pembelajaran dan mengetahui kegiatan-kegiatan apa saja yang dilakukan guru pada saat proses kegiatan pembelajaran berlangsung. 


\section{Refleksi}

Pada tahap ini peneliti membandingkan hasil pada siklus II dengan hasil pada siklus I. Apakah ada peningkatan hasil belajar siswa atau tidak, apabila tidak ada peningkatan hasil belajar maka siklus tetap dilanjutkan sampai berhasil, tetapi apabila berhasil maka peneliti dan guru sepakat untuk menghentikan siklus ini.

Teknik pengumpulan data dalam penelitian ini adalah menggunakan angket atau kuesioner untuk mengetahui minat belajar siswa. Adapun instrument berupa soal test digunakan untuk mendapatkan data mengenai tingkat penguasaan atau hasil belajar siswa pada kompetensi keahlian sistem bahan bensin yang. Data yang diperoleh melalui angket dan soal test, selanjutnya dilakukan analisis menggunakan statistik deskriptif yang disajikan melalui table, grafik, dan perhitungan sebaran data.

Indikator penelitian ini adalah meningkatkan minat dan hasil belajar siswa kelas XI TKR SMK Muhammadiyah Cangkringan. Peningkatan minat belajar dapat dilihat dari hasil angket dengan kriteria keberhasilan rata-rata persentase $\geq 70 \%$, sedangkan hasil belajar siswa dapat dilihat dari hasil tes siswa dengan menggunakan kriteria ketuntasan minimal yang telah ditetapkan sekolah yaitu dengan nilai ketuntasan 75. Maka dalam penelitian ini dikatakan berhasil apabila pemanfaatan metode pembelajaran Think Pair Share (TPS) dapat meningkatkan minat dan hasil belajar menjadi $\geq$ $70 \%$.

\section{HASIL DAN PEMBAHASAN}

\section{Minat Belajar}

Peningkatan minat belajar siswa dalam pembelajaran sistem bahan bakar bensin pra siklus dengan siklus I yang menggunakan model pembelajaran kooperatif Think Pair share (TPS) disajikan dalam Tabel 1.

Tabel 1. Persentase Minat Belajar Siswa Pra Siklus dan Siklus I

\begin{tabular}{ccc}
\hline Keterangan & Pra Siklus & Siklus I \\
\hline Jumlah Skor & 1579.17 & 1781,25 \\
Rata-Rata Persentase & $63.17 \%$ & $71,25 \%$ \\
Kategori & Baik & Baik \\
\hline
\end{tabular}

Berdasarkan Tabel 1, minat belajar pada pra siklus diperoleh data rata-rata persentase minat belajar siswa sebesar $63,17 \%$ termasuk dalam kategori baik, sedangkan pada siklus I rata-rata persentase minat belajar siswa mengalami peningkatan menjadi $71,25 \%$. Sehingga peningkatan minat belajar antara pra siklus dengan siklus I yang menggunakan pembelajaran TPS adalah sebesar $8.08 \%$. Oleh karena itu dapat dikatakan bahwa rata-rata persentase minat belajar siswa sudah mencapai target yang diharapkan yaitu dengan rata-rata persentase $70 \%$. Dengan demikian dapat disimpulkan bahwa ada peningkatan minat belajar siswa pada pembelajaran sistem bahan bakar bensin kelas XI TKR SMK Muhammadiyah Cangkringan setelah diterapkannya model pembelajaran Think Pair share (TPS). Sehingga pengukuran minat belajar siswa pada kompetensi atau mata pelajaran sistem bahan bakar bensin tidak dilanjutkan atau dilakukan pada siklus II.

Berdasarkan data diatas dapat diberikan deskripsi atau penjelasan bahwa adanya kenaikan atau peningkatan minat belajar pada siswa pada mata pelajaran sisitem bahan bakar bensin dikarenakan adanya penerapan model pembelajaran. Dengan penerapan model pembelajaran TPS memungkinkan siswa lebih aktif dalam proses belajar mengajar. Masing-masing siswa lebih dioptimalkan dengan menyelesaikan setiap soal yang menjadi tugasnya. Selanjutnya siswa dapat bekerja saya dengan teman atau pasangannya sebelum berdiskusi dengan teman kelompoknya dalam pembelajaran.

\section{Hasil Belajar}

Peningkatan hasil belajar siswa dalam pembelajaran sistem bahan bakar bensin pra siklus, siklus I, dan siklus II (penerapan TPS) disajikan dalam Tabel 2. 
Tabel 2. Data hasil belajar pra siklus, siklus I, dan siklus II

\begin{tabular}{lccc}
\hline \multicolumn{1}{c}{ Keterangan } & Pra Siklus & Siklus I & Siklus II \\
\hline Jumlah & 1815 & 2680 & 2895 \\
Rata-Rata & 50,42 & 74,44 & 80,42 \\
Nilai Maksimum & 75 & 90 & 95 \\
Nilai Minimum & 30 & 55 & 55 \\
Jumlah Nilai Di Bawah KKM & 29 & 12 & 5 \\
Persentase Nilai Di Bawah KKM & $80,56 \%$ & $33,33 \%$ & $13,89 \%$ \\
Jumlah Nilai Di Atas KKM & 7 & 24 & 31 \\
Persentase Nilai Di Atas KKM & $19,44 \%$ & $66,67 \%$ & $86,11 \%$ \\
\hline
\end{tabular}

Dari Tabel 2, maka dapat kita ketahui hasil nilai rata-rata siswa pra siklus dari 36 siswa yaitu 50,42. Sehingga nilai rata-rata siswa tersebut belum memenuhi KKM yang telah ditentukan di sekolah yaitu 75,00. Kemudian peneliti menerapkan metode pembelajaran kooperatif tipe Think Pair Share (TPS) yang dilaksanakan selama dua siklus yaitu siklus I dan siklus II.

Dalam siklus I, diperoleh data nilai rata-rata hasil belajar siswa mengalami peningkatan dibandingkan dengan nilai pra siklus yaitu 50,42 menjadi 74,44 pada siklus I, kemudian dilanjutkan dengan siklus II dan diperoleh nilai rata-rata 80,42. Sehingga dapat disimpulkan bahwa nilai ratarata siswa tersebut telah memenuhi KKM yang ditentukan yaitu 75,00. Adapun diagram peningkatan rata-rata hasil belajar siswa pada pra siklus, siklus I dan siklus II dapat dilihat pada Gambar 2.

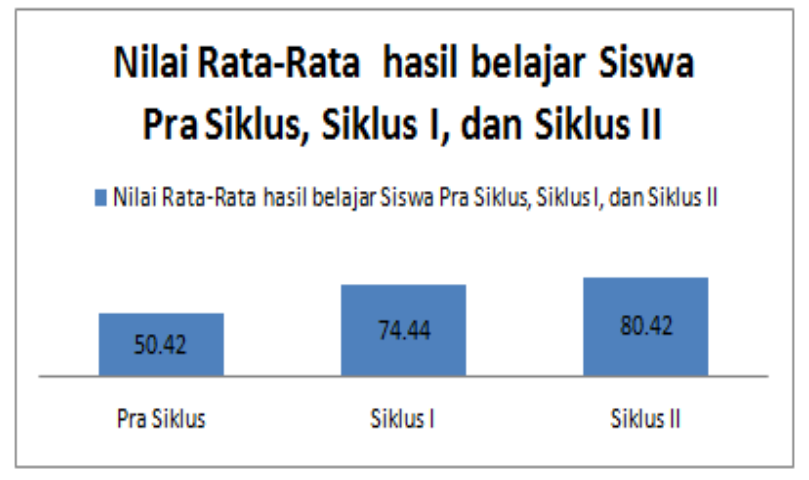

Gambar 2. Diagram Peningkatan Nilai Rata-Rata Hasil Belajar

Berdasarkan Gambar 2 dapat dijelaskan bahwa persentase pada tindakan pelaksanaan tes siklus I dan siklus II sudah terlihat adanya peningkatan dibandingkan pada hasil pra siklus, dimana pada pra siklus siswa yang belum memenuhi KKM sebanyak 29 siswa $(80,56 \%)$ dan siswa yang telah memenuhi KKM sebanyak $7(19,44 \%)$ sedangkan persentase hasil nilai pada siklus I siswa yang belum memenuhi KKM menurun menjadi 12 siswa $(33,33 \%)$ dan siswa yang telah memenuhi KKM bertambah menjadi 14 siswa $(66,67 \%)$, selain itu persentase hasil nilai pada siklus II juga mengalami peningkatan yaitu siswa yang telah memenuhi KKM bertambah menjadi 31 siswa $(86,11 \%)$ sedangkan siswa yang belum memenuhi KKM menurun menjadi 5 siswa $(13,89 \%)$ dari jumlah 36 siswa. Adapun perolehan persentase hasil belajar siswa pada pra siklus, siklus I dan siklus II disajikan dalam Gambar 3.

Berdasarkan Gambar 3 dapat diketahui bahwa ada peningkatan persentase rata-rata hasil belajar dan nilai hasil belajar siswa kelas XI TKR SMK Muhammadiyah Cangkringan dalam pembelajaran kompetensi keahlian sistem bahan bakar bensin. Peningkatan dapat dilihat pada pelaksanaan langkah pra siklus, siklus I, maupun pada siklus II. Persentase rata-rata hasil belajar pada siklus I lebih tinggi dari pada persentase rata-rata hasil belajar pada pra siklus. Hal ini membuktikan bahwa dengan pembelajaran atau pelaksanaan belajar mengajar dengan metode TPS dapat meningkatkan prestasi belajar pada siswa khususnya pada mata pelajaran sistem bahar bensin.

Adanya peningkatan prestasi belajar siswa setelah dilaksanakannya pembelajaran dengan metode TPS, hal ini dimungkinkan karena pembelajaran yang sebelumnya terpusat pada guru memungkinkan secara keseluruhan siswa tidak dapat terpantau secara maksimal. Ada dari sebagian mereka yang 
kurang memperhatikan selama proses belajar mengajar berlangsung. Akan tetapi dengan metode TPS memungkinkan masing-masing siswa akan terkondisi dengan tugasnya untuk menjawab atau menyelesaiakan masalah dengan berfikir, berpasangan, dan secara berkelompok berdiskusi, untuk selanjutnya menyampaiakan hasil diskusi kepada teman seluruh kelas.

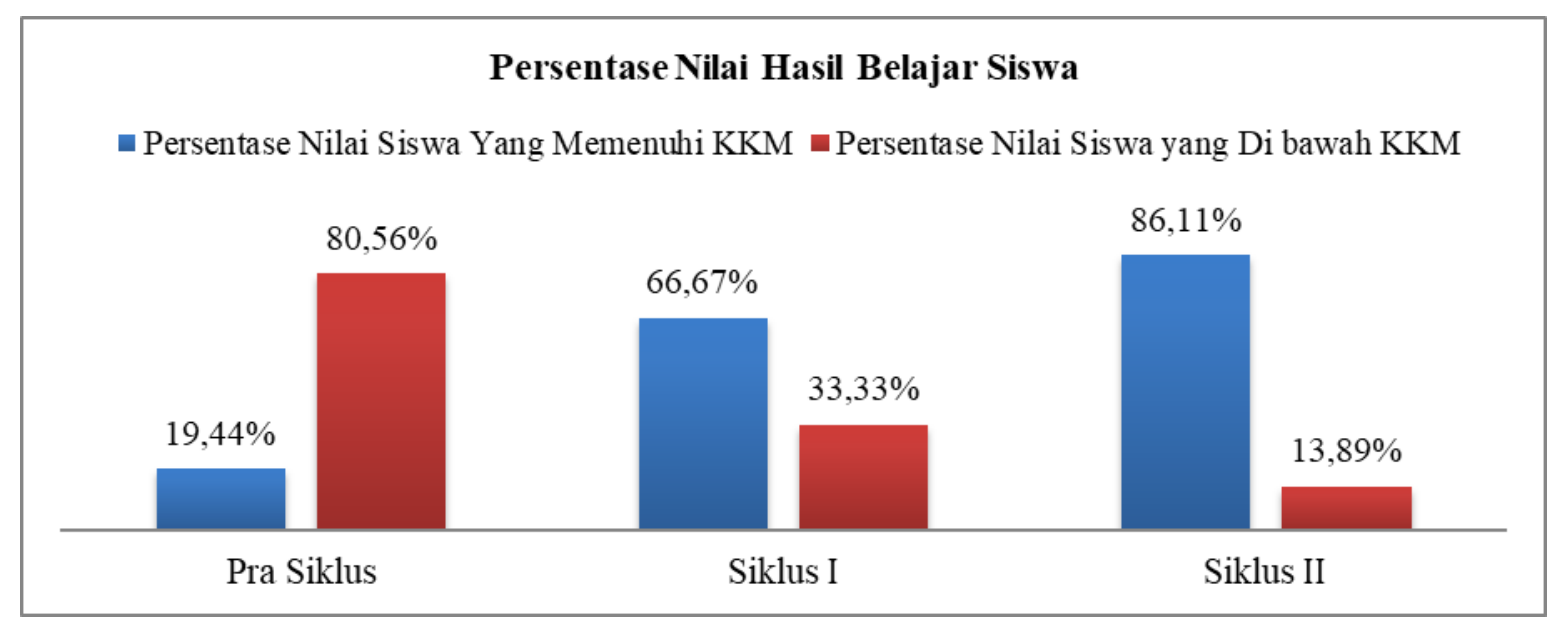

Gambar 3. Diagram Persentase Nilai Hasil Belajar

Pada siklus I yang dilakukan dengan pembelajaran metode TPS peningkatan hasil belajar belum dapat memenuhi dari indikator keberhasilan yang ditetapkan. Hal ini kemungkinan disebabkan karena banyak faktor, salah satunya adalah belum terbiasanya siswa dalam mengikuti proses belajar mengajar dengan metode TPS, karena pembelajaran yang berlangsung sebelumnya masih cenderung berpusat pada guru, sehingga kurang memaksimalkan keterlibatan siswa dalam proses pembelajaran. Oleh karenanya hasil data yang didapatkan dari pelaksanaan tindakan, observasi, dan refleksi pada siklus I dijadikan acuan atau referensi untuk melaksanakan langkah selanjutnya atau melanjutkan pada tahab siklus II.

Setelah dilaksanakan siklus ke II, didapatkan data bahwa ada kenaikan rata-rata hasil belajar siswa pada mata pelajaran sistem bahan bakar bensin. Nilai rata-rata hasil belajar yang sebelumnya pada siklus I adalah 74,44, maka pada pelaksanaan siklus ke II rata-rata hasil belajar adalah 80,42. Jika dilihat dari persentase nilai diatas KKM maka dapat dilihat pada pelaksanaan siklus ke II, nilai siswa yang diatas KKM adalah sebesar $86,11 \%$. Dengan demikian target atau indikator keberhasilan untuk peningkatan hasil sebesar $\geq 70 \%$ sudah terpenuhi, sehingga sudah tidak diperlukan lagi siklus berkutnya untuk mengetahui capaian keberhasilan atau prestasi belajar siswa.

Peningkatan hasil belajar siswa pada mata pelajaran sistem bahan bakar bensin yang cukup signifikan pada siklus ke II dimungkinkan dicapai karena siswa sudah dapat terkondisi dan memahami strategi atau model pembelajaran dengan TPS yang sudah diterapkan sebelumnya. Dengan demikian dapat disimpulkan bahwa penerapan model pembelajaran TPS dapat meningkatkan prestasi belajar siswa khususnya mata pelajaran sistem bahan bakar bensin.

\section{SIMPULAN}

Penerapan model pembelajaran kooperatif tipe Think Pair Share (TPS) pada kompetensi keahlian sistem bahan bakar bensin dapat meningkatkan minat dan hasil belajar siswa kelas XI TKR SMK Muhammadiyah Cangkringan. Pembelajaran dengan menggunakan metode TPS dapat meningkatkan minat belajar siswa. Rata-rata perolehan data minat belajar siswa pada pra siklus adalah $63,13 \%$, dan pada siklus I mengalami peningkatan menjadi 71,25\%. Pembelajaran dengan menggunakan metode pembelajaran TPS dapat meningkatkan hasil belajar siswa, Data penelitian menunjukkan bahwa pada pra siklus nilai rata-rata sebesar 50,42 dengan ketuntasan 19,44\% meningkat menjadi rata-rata 74,44 dengan ketuntasan $66,67 \%$ pada siklus I dan meningkat lagi rata-rata 80,42 dengan ketuntasan $86,11 \%$ pada siklus II dari jumlah 36 siswa. 


\section{REFERENSI}

Arikunto, S., Suhardjono, \& Supardi. (2010). Penelitian tindakan kelas. Bumi Aksara.

Gagne, E. (1985). The cognitive psychology of school learning. Mass Little Brown and Co.

Huda, M. (2012). Cooperative Learning metode, teknik, struktur dan model penerapan. Pustaka Pelajar.

Huda, M. (2013). Model-model pengajaran dan pembelajaran: Isu-isu metodis dan paradigmatis. Pustaka Pelajar.

Purwanto, N. (2011). Evaluasi hasil belajar. Pustaka Pelajar.

Slameto, S. (2013). Belajar dan faktor-faktor yang mempengaruhinya. Bina Aksara.

Sudjana, N. (2010). Penilaian hasil proses belajar mengajar. PT Remaja Rosdakarya.

Supridjono, A. (2012). Cooperative learning: Teori dan aplikasi Paikem. Pustaka Belajar.

Syah, M. (2013). Psikologi pendidikan dengan pendekatan baru. PT Remaja Rosdakarya.

Uno, H. B. (2007). Teori motivasi dan pengukurannya: Analisis di bidang pendidikan. Bumi Aksara.

Winkel, W. S. (1983). Psikologi pendidikan dan evaluasi belajar. Gramedia. 